\title{
Erratum to: New code site classification, amplification factors and normalized response spectra based on a worldwide ground-motion database
}

\author{
Kyriazis Pitilakis · Evi Riga · Anastasios Anastasiadis
}

Published online: 22 March 2013

(C) Springer Science+Business Media Dordrecht 2013

\section{Erratum to: Bull Earthquake Eng DOI 10.1007/s10518-013-9429-4}

Unfortunately there is a mistake in the appendix section of this article. The text below Table 10 should read:

${ }^{\text {a }} \mathrm{CC}=$ Country Code: 1 for Greece, 2 for Italy, 3 for Japan, 4 for Turkey and 5 for USA

${ }^{\mathrm{b}} \mathrm{New} \mathrm{SC}=$ Soil class according to the proposed soil classification scheme

${ }^{\mathrm{c}} \mathrm{EC} 8 \mathrm{SC}=$ Soil class according to EC8 soil classification scheme

The online version of the original article can be found under doi:10.1007/s10518-013-9429-4.

K. Pitilakis $(\varangle) \cdot$ E. Riga · A. Anastasiadis

Aristotle University of Thessaloniki, P.O.B. 424, 54124 Thessaloniki, Greece

e-mail: pitilakis@ civil.auth.gr

E. Riga

e-mail: eviriga@civil.auth.gr

\section{A. Anastasiadis}

e-mail: anas@ civil.auth.gr 